США: новые реалии

DOI: 10.23932/2542-0240 -2017-10-3-54-67

Jahara W. MATISEK

Northwestern University

633, Clark St, Evanston, USA, 60208

FRANKY@u.northwestern.edu

\title{
American Civil-Military Relations Since George Washington: Has Donald Trump Changed the Dynamic?
}

\begin{abstract}
ABSTARCT. To understand the impact President Donald J. Trump might have on civil-military relations in the United States of Ameri$c a$, requires a historical dissection and understanding of how the American military came into being and its relationship with political institutions over two centuries. Relying on historical antecedents, the future of the Trump administration's foreign policy and relations with its military will likely remain stable in status quo terms. However, Trump's demonstration of a "hands-off" approach to national security strategy appears to have given the US military more autonomy than is typical of most presidential administrations. While this would likely be a dangerous decision in most other countries, the institutional resilience of the American military and its normative and legalistic dedication to the United States government suggests that this newfound authority will likely prove beneficial given the complexity of the international system in the 21st century. Finally, I introduce the concept of post-Civil Military Relations where a military can still be dedicated to the political institutions of the state regardless of perceptions about credibility and legitimacy. Understanding such ideas will provide a framework of how American national security strategy will be developed and executed in the era of President Trump.
\end{abstract}

KEYWORDS: Civil-Military Relations, American Foreign Policy, Institutions, President Trump

FOR CITATION: Matisek J.M. (2017). American Civil-Military Relations since George Washington: Has Donald Trump Changed the Dynamic. Outlines of global transformations: politics, economics, law, 10 (3). 54-67. DOI: 10.23932/2542-0240 -2017-10-3-54-67

The views expressed in this article are those of the author and do not reflect the official policy or position of the Political Science department at Northwestern University, Buffett Institute for Global Studies, United States Air Force, Department of Defense, or the US Government. 
США: новые реалии

DOI: $10.23932 / 2542-0240-2017-10-3-54-67$

Джахара МАТИШЕК

Северо-Западный университет

Кларка ул.,633, Эванстон, 60208, США

FRANKY@u.northwestern.edu

\section{Военно-гражданские отношения в США со времен Дж. Вашингтона: изменил ли Д. Трамп их динамику?}

\begin{abstract}
АННОТАЦИЯ. Для того чтобы понять, каково потенииальное влияние президента Дональда Трампа на военно-гражданские отношения в Соединённых Штатах Америки, необходим исторический анализ становления американской армии и её отнотений с политическими институтами на протяжении двух последних столетий. Принимая в расчет предшествующий опыт, весьма вероятно, что внешняя политика администрации Трампа и её отношения с армией останутся стабильными, сохраняя действующий статус-кво. Однако продемонстрированный Трампом подход «невмешательства» в сферу наииональной стратегии безопасности, вероятно, даст американской армии большую автономность, в сравнении с её типичным положением в отношении предшествуюших президентских администраций. Несмотря на то, что в других странах подобный подход мог бы вызвать опасные последствия, институииональная устойчивость американской армии и её нормативная и правовая преданность правительству США, напротив, вызовут благоприятные следствия, учитывая сложность и комплексность современной международной системы. Наконеи, я предлагаю кониепт пост-гражданско-военных отношений, в
\end{abstract}

которых армия останется верной политическим институтам страны вне зависимости от оценок состоятельности и легитимности этих институтов. Понимание таких идей позволит выработать видение того, каким образом американская национальная стратегия безопасности будет разработана и имплементирована в годы президентства Трампа.

КЛЮЧЕВЫЕ СЛОВА: военно-гражданскИе отношения, внешняя политика США, институты, президент Д. Трамп

ДЛЯ ЦИТИРОВАНИЯ: Матишек Дж. (2017). Военно-гражданские отношения в США со времен Дж. Вашингтона: Изменил ли Д. Трамп их динамику? Контуры глобальных трансформаций: политика, экономика, право, 10 (3). 54-67. DOI: 10.23932/2542-0240 -2017-10-3-54-67

Взгляды, изложенные в настоящей статье, принадлежат автору и не отражают обициальную позицию департамента потитической науки Северо-Западного университета, Института глобальных исследований им. Баффета, Военно-воздушных сил США, Министерства обороны или правительства США. 


\section{Introduction}

The United States of America has a longstanding tradition of a strong military that rarely meddles in domestic politics. Similarly, political leaders have rarely intruded in the affairs and operations of the United States (US) military. Indeed, the few times there has been strife between American political leaders and military flag officers (generals and admirals), it has usually been over procedures and policy during periods of internal crisis and war. With the recent inauguration of President Donald J. Trump, a man that while campaigning boasted "I know more about ISIS than the generals do...Believe me," some political scientists, commentators, and pundits have worried that such an attitude is likely to be corrosive to military institutions and the way Americans view their military ${ }^{1}$.

For many, it has been correct to question Trump's comments while he was a private citizen on the campaign trail, though most of it appears to have been political bloviating - meant to generate enthusiasm and votes. Nonetheless, in the short-time that Trump has been in office, he has assumed the role of a deferential commander-in-chief that increasingly delegates political decisions concerning national security strategy to the Pentagon. This has also included the appointment of retired flag officers to run parts of his cabinet and administration. Nonetheless, it has become clear that Trump is somewhat similar - in practice and in exercise of military power - to the 43 other presidents before him². The only stark contrast appears to be Trump's decision to be so "hands off" on military policies, procedures, and strategies ${ }^{3}$.

In many ways, the US has been incredibly lucky with its relations between political actors and military institutions. The first American president, George Washington, who had been incredibly successful as a Continental Army General during the Revolutionary War, could have established a monarchy, and yet chose not to despite tremendous support to do so. Instead, Washington's decision to run for president in a democratic manner and serve only two terms set a precedent for how active and retired military personnel should behave politically. It also established how future American presidents should behave and interact with military institutions (Cross, 2012). Washington's behavior established a set of key norms and values that has been a foundational aspect of American civil-military relations to this day. This is not to say there have not been disruptions, such as when President Abraham Lincoln fired numerous Army generals during the American Civil War (1861-1865) until ending up with the most competent of them all: Ulysses S. Grant (Harry, 2011). On the flip side more recently, a chief complaint levied against the Obama administration was its micromanagement of the commanders personally overseeing operations and tactics in the wars of Iraq, Afghanistan, and elsewhere ${ }^{4}$.

The only question now is if the "disruptive leadership style" of President Donald Trump

\footnotetext{
1 Reno W. The Coming "Day One" Challenge to Trump's Foreign Policy. Small Wars Journal. January 21, 2017. URL: http://smallwarsjournal. com/jrnl/art/the-coming-\%E2\%80\%9Cday-one\%E2\%80\%9D-challenge-to-trump\%E2\%80\%99s-foreign-policy (Accessed: 18.04.2017); Johnson J. Donald Trump begs lowans not to believe Ben Carson: 'Don't be fools, okay?. The Washington Post. November 13, 2015. URL: https://www.washingtonpost.com/news/post-politics/wp/2015/11/13/donald-trump-begs-iowans-not-to-believe-ben-carson-dontbe-fools-okay/?postshare=2221447428349529\&tid=ss_tw\&utm_term=.a4e617b934f5 (Accessed: 18.04.2017); Matisek J.M. "The Danger of Trump to Civil-Military Relations," Cicero Magazine, 18 June 2016. Available at SSRN: https://ssrn.com/abstract=2912612 (Accessed: 18.04.2017); Richardson V. Los Angeles Times runs op-ed promoting military coup against Donald Trump. The Washington Times. July 20, 2016. URL: http://www.washingtontimes.com/news/2016/jul/20/los-angeles-times-runs-op-ed-promoting-military-co/ (Accessed: 18.04.2017)

2 Jackson D. Is Donald Trump the 44th or 45th president?. USA Today. January 20, 2017. URL: https://www.usatoday.com/story/news/ politics/onpolitics/2017/01/20/donald-trump-44th-45th-president-grover-cleveland/96832494/ (Accessed: 18.04.2017)

3 Brands H. 6 Things We Know About Trump's Foreign Policy After 100 Days. Foreign Policy. April 26, 2017. URL: http://foreignpolicy. com/2017/04/26/6-things-we-know-about-trumps-foreign-policy-after-100-days/ (Accessed: 18.04.2017)

4 Sisk R. Gates and Panetta Blast Obama for Micromanaging Military. URL: http://www.military.com/daily-news/2014/11/17/gates-andpanetta-blast-obama-for-micromanaging-military.html (Accessed: 18.04.2017)
} 
will fundamentally change the dynamics of how presidents interact with their military institutions and the way policy and strategy is enacted $^{5}$. Or could military institutions and personnel serve as a calming force on his behavior, leading Trump to utilize his military in a status quo fashion that strikes the right balance of civilian control but enough autonomy for the military to be successful. Many domestic and international problems have already been caused by his $3 \mathrm{am}$ Tweets, official calls that confuse/anger dignitaries, and "alternative fact" behavior at campaign rallies, just to name a few ${ }^{6}$. Nonetheless, it appears that George Washington's remarks to Congress in 1790 that being "prepared for war is one of the most effective means of preserving peace" will remain an enduring narrative in which American civil-military relations will persist ${ }^{7}$. Trump's appointment of retired Marine Corps General James Mattis as the Secretary of Defense and Army Lieutenant General H.R. McMaster as the National Security Adviser appears to fit this narrative of an administration serious about national security and foreign policy, and a desire to have strategies that mirror Pentagon recommendations.

It seems likely that the path dependence of US military institutions are 'stickier' than most scholarship might expect, and that its professionalization is so institutionalized and embedded autonomously that a coup seems impossible, despite an editorial in the Los Angeles Times suggesting it as a possibility ${ }^{8}$. Despite such weddedness to the structure of the US government, it is becoming increasingly obvious that the American military will continue to pursue actions that allow it to operate more independently from civilian control, but ultimately still draws on the formal authority of the president, while relying on Congress to provide funding. In this vein, the Trump administration appears poised to give the American military more control over the wars in Iraq, Afghanistan, and elsewhere.

\section{Historical Context of American Civil-Military Relations}

Since the founding of the rebellious republic, the US has had a paradoxical relationship between its political institutions and military institutions. On one hand, there has been a hesitancy to build up too much of a military due to the costs and burdens imposed on the American taxpayer and government. However, there has been a consistent desire to secure certain hegemonic spheres of control (e.g. Truman Doctrine) and economic advantages in trade and finances, which has required the use of expeditionary military forces to achieve such ends. Of course, much of this stammering on how much of a standing military to maintain was an argument primarily built on the simple structural condition that the US had benign neighbors to the north (Canada) and south (Mexico) with massive bodies of water (Pacific and Atlantic Ocean) separating the US from the troubles in Asia and Europe. Hence, US political leadership could pursue policies that gave great latitudes to their military, while constraining it through budgets that kept it small and limited in scope.

In many ways, George Washington "could have been a king". His leadership and great military victories against the powerful military of Great Britain elevated him to celebrity status to domestic and international audiences alike. Instead, Washington's inclination

\footnotetext{
5 Whelan C. Donald Trump's 'disruptive' leadership style presents huge problems for Homeland Security. Public Radio International: The World. January 30, 2017. URL: https://www.pri.org/stories/2017-01-30/donald-trumps-disruptive-leadership-style-presents-hugeproblems-homeland (Accessed: 18.04.2017)

6 Jackson D. Trump's calls and tweets on foreign policy are threatening rivals, allies. USA Today. February 2, 2017. URL: https://www. usatoday.com/story/news/politics/2017/02/02/donald-trump-mexico-australia-iran/97388142/ (Accessed: 18.04.2017)

7 George Washington. First Annual Address, to both Houses of Congress. January 8, 1790.

8 Kirchick J. If Trump wins, a coup isn't impossible here in the U.S. Los Angeles Times. July 19, 2016. URL: http://www.latimes.com/ opinion/op-ed/la-oe-kirchick-trump-coup-20160719-snap-story.html (Accessed: 18.04.2017)
} 
after leading a successful military revolution against the British and his two terms as president was to simply "return to his farm (Boaz, 2006) $)^{9}$. Such a reluctance for raw military power and a deference towards keeping control of the government on democratic terms, and keeping its power minimal, facilitated the creation of rule-bound American institutions endowed with strong informal norms and values. This is exactly why Samuel Huntington considered the US as being unique for having informally adopted the Tudor system of governance from the British - all without having to rely on a monarchial power or overly strong state. These Tudor customs effectively served as a modicum of social contracts between the state and citizens (Huntington, 2006).

Such norms effectively also translated into the military accepting a subservient role to political leadership as had also been the case in Britain at the time. Later in the 19th century, Clausewitz would proclaim the importance of militaries being subordinated to political control, much as it was codified in the US Constitution. Such subservience has been an enduring civil-military relations principle in Western military literature and doctrine. Indeed, there is a reason why "obedience is assumed" because there is over 200 years of American military history showing this civil-military custom to be true day in and day out ${ }^{10}$.

\section{Presidential Frictions with Military during Wartime}

Fundamentally, the US military is primarily controlled and operated by its own leadership institutions internally. However, the American president is the commander-inchief, and is officially in charge of all military decisions and actions. The truth and reality to this is that there are numerous bureaucratic layers between the president, strategy, personnel decisions, war-planning, operations, and tactical outcomes on the battlefield. This is poignant because it illustrates the need for the American military to operate independently of strict subjective civilian control (i.e. micromanaging of military decisions by politicians). Hence, in many ways the American military has primarily operated through objective military control measures, where military leaders are given extensive latitudes in the ability to plan military campaigns, create some strategy, and fully execute military operations at the tactical level. Nevertheless, this leads to various frictions between presidents and flag officers that both want the same end state (victory), but see different operational and tactical means of achieving that end.

While the US emerged victorious against the British in the American Revolutionary War (1775-1783), deliberation about armies in European history by the Founding Fathers led them to see a large standing military as a potential instrument of tyranny (Maslowski, 1986, 212). At the same time however, despite emerging victorious, the threat posed by indigenous tribes, bandits, pirates, rebels, and other global powers (such as the British, French, Spanish, etc.) meant the US needed some modicum of military strength to expand the fledgling nation westward while protecting and deterring its exposed flanks from intruders. The penultimate solution to the possible tyranny and threat dilemma resulted in a compromise between political control and military effectiveness. In this case, there was a belief in a "trusted balance, the diffusion of power, and shared responsibility - all basic elements of the new political system - to control the military" (Johnson, 1995, p. 3). This meant that various political and governmental institutions were responsible for interacting with (and overseeing) the military leading to a harmonious relationship.

\footnotetext{
9 Boaz D. The Man Who Would Not Be King. CATO Institute: Daily Commentary. February 20, 2006. URL: https://www.cato.org/publications/ commentary/man-who-would-not-be-king (Accessed: 18.04.2017)

10 Kohn R. Richard Kohn fires a warning flare about a Joint Force Quarterly article. Foreign Policy. September 29, 2010. URL: http:// foreignpolicy.com/2010/09/29/richard-kohn-fires-a-warning-flare-about-a-joint-force-quarterly-article/ (Accessed: 15.04.2017)
} 
This is not to say there has not been strife between American political leadership and its military. Indeed, the birth of the American nation was not as smooth as most school texts typically portray it as. As hostilities were concluding between colonial troops and British soldiers, the fledging Republic was struggling to pay its troops involved in the war effort. In what would later be known as the Newburgh Conspiracy, a group of disgruntled officers living on credit - led by Major John Armstrong Jr., "lobbied" Congress in 1783 about ensuring they received proper remuneration for their military services. He effectively implied a possible mutiny if pay was not approved by the legislative body (Kohn, 1970, p. 188-220). This is probably the closest the US has ever come to a military coup. While the entire incident is still debated among historians, it is significant because there are numerous documents showing Continental Army discontentment with irregular payments. In addition, the perception that Congress would not follow through on pensions was enough to lead some officers to write a letter to Congress insinuating the threat of insurrection stating "any further experiments on their patience may have fatal effects" (Kirby et al., 2015, p. 195). The only braking effect on this was General Washington giving an eloquent speech to possible defectors in March of 1783, imploring that any attempt to coerce Congress into payment would be "an assault on his own integrity" (Ellis, 2005, p. 142). Needless to say, Washington's intervention put an end to all future talk concerning mutiny against the Congress, while it also facilitated payment plans agreeable to most Continental Army troops.

Since that time, sporadic tensions have occurred between American presidents and their flag officers over nuanced disagreements on military policy and war-time strategies. For example, in 1818 Army General Andrew
Jackson was ordered to the border of Spanish Florida to stem cross-border raids by Seminoles against plantation owners in neighboring states. Taking the initiative, Jackson decided to invade the sovereign Spanish territory without any authorization from Congress or President Monroe. To that end, Jackson quickly routed the Spanish military, expelling Spanish rulers and military personnel. However, Jackson had never been authorized to invade Spanish Florida, leading some, such as the Secretary of War John C. Calhoun to recommend a reprimand due to the international incident Jackson had caused. Fortunately for Jackson, the Spanish relinquished control of the territory in exchange for about $\$ 5$ million worth of debt relief, and Monroe opted not to punish Jackson for his unauthorized actions due to the positive foreign policy outcome ${ }^{11}$.

As noted in the introduction, President Lincoln fired numerous generals during the American Civil War, to include some that had won important battles against the best Confederate General, Robert E. Lee. However, it is important to note that while the American Civil War was not a coup per se, it was a southern secessionist movement away from the North. This resulted in a significant portion of the US military in the South breaking away from the federal government and establishing itself as the Confederate Army. Following the triumph of the North over the South, President Andrew Johnson issued a Proclamation of Amnesty and Pardon within months, permitting southerners to regain their US citizenship, except for 14 categories that were primarily high-ranking officials and officers involved in the Confederate rebellion ${ }^{12}$. Such actions while controversial, permitted a smoother transition towards the reconstruction period, and enabled American battlefield success in future wars, as former Confederate troops and officers would serve together

\footnotetext{
11 James Monroe: Foreign Affairs. University of Virginia: Miller Center. 2017. URL: https://millercenter.org/president/monroe/foreignaffairs (Accessed: 18.04.2017)

12 General Robert E. Lee's Parole and Citizenship. The U.S. National Archives and Records Administration. 2005. URL: https://www. archives.gov/publications/prologue/2005/spring/piece-lee.html (Accessed: 18.04.2017)
} 
in the Spanish-American War (1898), as they achieved quick battlefield victories in Cuba, Puerto Rico, Guam, and the Philippines.

Further significant civil-military strife would emerge during the Korean War (19501953), where US Army General Douglas MacArthur became insubordinate. While a successful general from World War Two, MacArthur during the Korean War saw himself as being independent from political control in Washington to wage the war he desired in the Korean peninsula to defeat the Communist forces of North Korea and China. Unfortunately, his provocations alarmed President Harry Truman and allies, especially in context of the possibility of him wanted to use nuclear weapons and his desire to engage in an allout war with China (Brands, 2016). Losing confidence in MacArthur, Truman had to fire him despite knowing it would hurt his own popularity, which it did. Such unpopularity surrounding the firing of MacArthur led to Truman not running for a second term as president even though it was a correct decision to fire a renegade general.

The Vietnam War would create a situation in which the American military leadership would be too deferential to presidential decision-making. As identified by H.R. McMaster, the Vietnam War was not a failure of civil-military relations because of presidential meddling in day to day military affairs and operations, as had been suggest by some historians regarding President Lyndon Johnson holding weekly lunch sessions to choose which targets to bomb (Calhoun, 1993, p. 136-139). Instead, it was the failings of high-ranking generals on the Joint Chiefs of Staff to establish a consensus on how to conduct the war in a meaningful fashion, primarily because they were more concerned about inter-service rivalries than they were in trying to win a war in Vietnam (McMaster, 1998). But the grander observa- tion to be derived from the American debacle in Vietnam was that it was a war in which the US was so incredibly successful tactically, and yet lost strategically (Høiback, 2013).

Following the Cold War, there was an end to the perception of a significant external threat to the US and her national interests. The lack of international strife led President Bill Clinton to embark upon numerous domestic military reforms. The most contentious of them all resulted in General Powell telling the Clinton administration that there would be a massive resignation of flag officers if he "forced the gay issue" (Faderman, 2015, p. 499). Such a threat against Clinton did not result in a purge of the American officer corps, but instead led to the creation of a compromise known as the "Don't Ask, Don't Tell" policy. This allowed Clinton to please his base while allowing the military to operate without disruption to the status quo.

Since the attacks of 9/11, American civilmilitary relation strife has primarily centered around how to best manage and conduct wars. For example, in the lead up to the invasion of Iraq in 2003, the Army Chief of Staff, General Shinseki, briefed Congress that he would need "several hundred thousand soldiers" to stabilize Iraq in a costly post-conflict phase ${ }^{13}$. However, Shinseki's truth-bomb would lead to him being reprimanded by the Deputy Secretary of Defense, Paul Wolfowitz, because his comments on a possible Iraq War did not fit the desired Bush administration narrative at the time ${ }^{14}$. In hindsight, it is obvious that Shinseki's recommendations were more likely correct concerning troop levels and costs for stability operations in Iraq, but this did not mesh well with Bush's attempts to make the prospect of a war in Iraq an 'easy sell'.

More recently, President Barack Obama had to contend with his flag officers seeking alternative US military policies. For example,

\footnotetext{
13 Mills N. Punished for telling truth about Iraq war. CNN, March 20, 2013, URL: http://www.cnn.com/2013/03/20/opinion/mills-truthteller-iraq/ (Accessed: 18.04.2013)

14 Schmitt E. Threats and Responses: Military Spending; Pentagon Contradicts General on Iraq Occupation Force's Size. The New York Times, February 28, 2003. URL: http://www.nytimes.com/2003/02/28/us/threats-responses-military-spending-pentagon-contradictsgeneral-iraq-occupation.html?_r=0 (Accessed: 18.04.2013)
} 
the Obama administration tried to devise a new strategy on the war in Afghanistan, which was a campaign promise. However, a report created by General Stanley McChrystal was leaked to the press that advocated for a surge of 40,000 to 80,000 American troops because the mission in Afghanistan was approaching "mission failure" 15 . This incident caused the Obama administration to reluctantly commit more troops to the war in Afghanistan than they had originally wanted, and against the wishes of the US Ambassador (Karl Eikenberry) to Afghanistan at the time ${ }^{16}$. However, McChrystal's success in forcing Obama's hand on troop commitments to Afghanistan would be short-lived. He and his staff exhibited a high level of hubris concerning their ability to wage the war in Afghanistan independent of US political leadership desires. This was put on full display when McChrystal and his team decided to openly mock the Obama administration in a Rolling Stones interview piece $^{17}$. Such behavior led to Obama having to fire McChrystal for the purposes of ensuring "unity of effort... [in] our objectives in Afghanistan"18.

\section{Traditional Notions of American Civil-Military Relations}

Before further discussing military interference domestically, it is important to parse out the means and ends of such attempts and behavior by the US military in its conduct. First, most literature on civil-military relations is effectively concerned with the simple problem of civilian institutions attempting to control its military. To this end, this control paradox has usually been translated into Peter Feaver's problematique, where the institutions responsible for violence (i.e. the military) can remain subservient to their political institutions, and not engage in a coup d'état (Feaver, 1999, 211-241).

The canonical basis of such Western ideas concerning this problematique are most prominently traced back to the writings of the political scientist Samuel Huntington's The Soldier and the State, where he focused on how to best control military institutions so that they could still be effective in war but not take over their own government ${ }^{19}$. To that end, Huntington believed that conservative thinking military personnel needed to be professionalized through education, which would make them legally and normatively bound to defer to their more liberal civilian authorities (Huntington, 1957). Describing a different aspect of this problematique, the sociologist Morris Janowitz authored The Professional Soldier, arguing that there was a sort of convergence between military institutions and civil society. Within this framework, Janowitz believed that effective civilian control of the military would occur through the military becoming more 'civilianized' while society became "militarized" simultaneously (Janowitz, 1961).

Until the Cold War, the American public and political leadership had rarely permitted the existence of a large standing army out of distrusts that became sociologically engrained in the culture of America (Lengel, 2012). Indeed, founders of the US, such as James Madison proclaimed at the Constitutional

15 Hastings M. The runaway general. Rolling Stone. June 22, 2010. URL: http://www.rollingstone.com/politics/news/the-runawaygeneral-20100622. (Accessed: 18.04.2017)

16 Baker P. "How Obama Came to Plan for 'Surge' in Afghanistan," The New York Times, 5 December 2009. URL: http://www.nytimes. com/2009/12/06/world/asia/06reconstruct.html(Accessed: 18.04.2017)

17 Shachtman N. McChrystal apologies for Incendiary Article. Wired. June 21, 2010. URL: https://www.wired.com/2010/06/mcchrystalapologies-for-incendiary-article/(Accessed: 18.04.2017)

18 Cooper H, Sanger E. Obama Says Afghan Policy Won't Change After Dismissal. The New York Times. June, 23, 2010. URL: http://www. nytimes.com/2010/06/24/us/politics/24mcchrystal.html?pagewanted=all\&_r=0 (Accessed: 18.04.2017)

19 One could also entertain the fact that Clausewitz was the first prominent author to bring it up in On War in the 19th century, while Sun Tzu alluded to the need for military commanders to put their faith in following the orders of their political leaders in The Art of War in the 5 th century B.C. 
Convention that "A standing military force, with an overgrown Executive will not long be safe companions to liberty" ${ }^{\prime 2}$. The experience of British occupation in colonial America, in conjunction with substantive historical evidence of costly and liberty-crushing armies in Europe gave just rationale for creating the third constitutional amendment dedicated specifically to limiting the aim of the military: "No Soldier shall, in time of peace be quartered in any house, without the consent of the Owner, nor in time of war, but in a manner to be prescribed by law" (Black, 1960, p. 865).

Oddly, the next significant progression in positive civil-military relations would be a product of the American Civil War. During the Reconstruction Period (1865-1878), the US military was regularly deployed to the South to ensure all federal laws were being followed, to include protecting polling stations where blacks were voting. Such deployments of federal troops to enforce domestic laws, especially at polling stations, led to much resentment in the South. The Posse Comitatus Act of 1878 emerged as a cynical deal to restrict the ability of the US military to enforce domestic laws, while simultaneously helping forge a strong union between north and south. With its passage, the US military was forbidden from enforcing domestic laws and engaging in any sort of civil policing without explicit orders from the executive and legislative branches of the federal government. This Act has legally bound the American military to refrain from even the most basic of policing duties and humanitarian activities without explicit legal reviews, to include ensuring approval and consent from state and federal authorities.

Despite these differing views and takes on processes that lead to a military that is subservient to political leadership, this has only helped to explain why the American military has never attempted a coup. Such formative civil-military literature beyond the aspect of coups is less clear. Understanding how and when the American military deviates from civilian control or attempts to pursue different policies or shape a debate on a conflict is much more of a principle-agent problem (i.e. 'shirking') than an issue of a military that chooses to formally take control of their government (Feaver, 2009). This is not to say that the military has not tried to keep politicians out of the day-to-day operations of war at the tactical level, such as the emergence of US Army doctrine (Field Manual 100-5) in 1982. Unfortunately, such doctrinal attempts at filtering out political meddling in military operations and tactics has failed to produce the intend effect ${ }^{21}$.

A final aspect of civil-military relations that receives less attention, involves smaller events, such as the type and level of involvement of the military in American society and politics. For instance, sparse amounts of literature pertain to the good the American military has done domestically, such as how the US Army Corps of Engineers came to dominate domestic management of natural resources, to include directing the development of civic policies towards water, timber, oil, minerals, and so on (Feldman, 1987, p. 229-244). The Army Corps of Engineers, established in 1775 , has served as an interesting military institution that has influenced and interreacted with various components of the legislative and executive components of state and federal governments. Considering this, it becomes increasingly important to understand what will happen to the US military and its relationship to society based on President Trump's newest budget proposal to increase the Defense Department budget by $\$ 54$ billion by cutting a host of domestic programs and other federal and international agencies, such as the State Department and the United Nations ${ }^{22}$.

20 Madison Debates. June 29, 1787. URL: http://avalon.law.yale.edu/18th_century/debates_629.asp (Accessed: 18.04.2017) 21 See: McGrew M.A. Politics and the operational level of war. School of advanced military studies United States Army Command and General Staff College. Fort Leavenworth, Kansas. AY 2010-2011.

22 Cohen Z. Trump proposes $\$ 54$ billion defense spending hike. CNN Politics. March 16, 2017. URL: http://www.cnn.com/2017/03/16/ politics/donald-trump-defense-budget-blueprint/ (Accessed: 18.04.2017) 


\section{Post-Civil-Military Relations in the Era of Trump}

There is somewhat of a lesser crisis facing American civil-military relations, that of the military tackling non-military problems. In many ways, it reflects the concerns first espoused by Harold Laswell in 1941 when he mused about the rise of garrison states based on the development of advanced weapon technologies (i.e. air power). In such a proposed scenario, Laswell envisioned that individuals with the most skills and aptitude to exercise violence would become a part of the political-military elite, effectively being primed to run the government (Lasswell, 1941, p. 455-469). Such reasoning was grounded in established notions of historical examples showing that military power translated into the strength of the state. The problem of such a garrison state coming into existence would be that it would drain the economy of resources in pursuit of a military while sapping the politics of society. Aaron Freidburg contended that such a scenario played out in Soviet Union during the Cold War, leading to the ultimate demise of the Soviet political system (Friedburg, 1992, p. 109-137).

Too much attention however on domestic affairs, however, is exactly why a controversial article written by U.S. Air Force Lieutenant Colonel Charles J. Dunlap, Jr., won the Chairman of the Joint Chiefs of Staff 1991-92 Strategy Essay Competition. Dunlap lamented how much the American military had gotten involved in domestic policing actions, such as the war on the drugs. Additionally, he foresaw the military becoming overly involved in non-military operations, to include providing domestic services to American citizens, which neutered its ability to be effective in combat operations (Dunlap, 1992, p. 2-20). Unfortunately, such domestic actions per Dunlap undermined the American government, as he astutely identified that citizens trusted the military more than any other institution in the
US. His article was a wakeup call to an American public and military that was seeing peace dividends in a post-Cold War order, while expecting the military to take on more domestic and international burdens not directly related to conventional warfare. Unfortunately, little has changed since Dunlap's article.

Rosa Brooks' 2016 book How Everything Became War and the Military Became Everything shows how the war-footing of the US since 9/11 has resulted in a military being tasked with more jobs and responsibilities beyond its original mandate and scope (Brooks, 2016). This increased workload on the American military has led to it gaining a larger chunk of the US budget to engage in peace operations and nation-building projects, while other agencies traditionally responsible for such activities have been slowly defunded and understaffed. The only saving grace within this contemporary shift in American civil-military relations is that the American public has retained its utmost commitment and support for the US military, while military personnel have remained astutely devoted to the principles and ideas of the American Republic.

A 2016 Gallup survey on American attitudes towards institutions showed that the US military was the most trusted institution, with 73 percent trusting it, whereas Congress was the least trusted at 9 percent. When Dunlap published his article in 1992, the American public similar confidence in the military at 69 percent, with Congress rated at 18 percent $^{23}$. Thus, the only constant since the end of the Cold War is American confidence in its military, whereas Congressional approval has slowly declined. Despite the mismatch in confidence, Americans trust the military to refrain from intervening domestically, and military professionals only seek clear strategy from political leadership in trying to be successful with all the military operations it has been tasked with in a post-9/11 environment.

23 Confidence in Institutions. Gallup. June 2016. URL: http://www.gallup.com/poll/1597/confidence-institutions.aspx (Accessed: 18.04.2017) 
Before Trump even assumed office, a Military Times survey showcased that 51 percent of active-duty military personnel were supportive of their new president. However, about a quarter of respondents in the survey indicated their concern that Trump "may issue orders that violate military rules or traditions". From these initial findings, follow-up interviews with personnel in the US Armed Forces indicated three broad sociological findings in context of the persistent controversy and speculation about Trump coordinating with Russian officials during the electoral process. First, approximately half of respondents indicated resentment towards the American political system due to their frustration with the wrong direction the US was moving towards. Such conservative attitudes are in line with what Huntington saw as a persistent issue in the military back in 1957. Second, many military personnel indicated a belief in legal procedures, and that if Trump had violated election laws that Congress would follow procedures accordingly to deal with such a precarious situation. This illustrates a desire by most military members that the political system has its own structure for dealing with unlawful behavior. Finally, and more interestingly, many American military personnel indicated a sense of apathy towards the ultimate outcome of any investigation against Trump. Indeed, it is quite telling of the state of American civil-military affairs when a high-ranking military officer admits that even if Trump had violated the law and was perceived as being effectively illegitimate that "it's almost impossible to stop the train at this point", indicating that the US military is devoted more to its political and military institutions than any precepts of presidential power or legal authority ${ }^{24}$. Such devotedness by military professionals to the political sys- tem despite it possibly lacking the perception of credibility and legitimacy suggests that we are operating in a post-Civil-Military Relations era.

What makes this post-Civil-Military Relations era significant for the US? In other countries with weaker political and military institutions, when there is a perception of "democratic backsliding", that military will typically intervene domestically as was seen in Egypt in 2013, or the failed coup attempt in Turkey in 2016. (Clark, 2007, p. 141-155) Regardless, Trump's decision to appoint numerous ex-military officials to his administration indicates his willingness to forego explicit civilian control of the military. In fact, since the creation of the Secretary of Defense position in 1947 , that job has almost always been filled by technocrats or politicians, with most having little to no experience in the military. George C. Marshall (1950-1951) and now James Mattis are effectively the only two retired generals to ever serve as a Secretary of Defense. While some pundits might view the appointment of numerous ex-military officials as an internal coup or the creation of a garrison state, it is more probable that Trump's governance style indicates his desire to appoint the most accomplished military personnel to operate the complicated war machinery of the US. To that end, Trump appears to have "learned" from these retired generals, as he has effectively walked back almost all disruptive foreign policy ideas he had originally campaigned on (e.g. charging NATO countries for defense, not attacking Syria, etc. ${ }^{25}$. Trump's success in national security strategy will now be dependent upon his ability to provide top-cover and resources to his military institutions to successfully deter adversaries and fulfill promises to eliminate terrorism.

\footnotetext{
24 Matisek J.W. Trump's Russian Cyber-Hack Controversy: New era of post-Civil-Military Relations? Duck of Minerva. January 18, 2017. URL: http://duckofminerva.com/2017/01/trumps-russian-cyber-hack-controversy-new-era-of-post-civil-military-relations.html (Accessed: 18.04.2017)

25 McFaul M. Is Trump learning - or ad-libbing - on foreign policy?. The Washington Post. April 28, 2017. URL: https://www.washingtonpost.com/news/global-opinions/wp/2017/04/28/is-trump-learning-or-ad-libbing-on-foreign-policy/?utm_term=.a6dc4b341727 (Accessed: 28.04.2017)
} 


\section{Conclusion}

While being interviewed by Fox News, Trump as a presidential candidate responded to a question about fighting the Islamic State by stating "There's nobody bigger or better at the military than I am" ${ }^{26}$. Such comments like this, to include a proclamation about killing the families of terrorists led to numerous retired flag officers to respond to Trump's rhetoric with "The military is not his palace guards" and that the American military "would refuse to act" if ordered to violate domestic or international law ${ }^{27}$. However, in practice, Trump has essentially dovetailed with Defense Department policies, to include giving them more authority to decide when to use military force (and escalate it when necessary) in their respective areas of responsibility ${ }^{28}$.

Regardless of these issues, it seems that President Trump has adeptly navigated the civil-military waters his first 100 days in office, by appointing highly capable and effective military personnel (active and retired) to positions of great importance, resulting in policies that align more closely with the desires of Defense Department. While there is a rich history of American civil-military strife in relations dating back to Independence, the US military has ultimately been effective in removing itself from the worst of domestic political problems, and has primarily developed a professional cadre of officers dedicated normatively and sociologically to the institutions and ideas of the American Republic. There is a reason why the premier military historian stated that "The unbroken record of subordination and loyalty by the
American armed forces under the Constitution of the United States, has been a blessing of the American political system, and the envy of nations the world over" (Kohn, 1991, p. 87). In many ways, this trend appears to be on course if Mattis and McMaster oversee American foreign policy, regardless of what Trump may Tweet or announce at a campaign rally.

However, the greater challenge to Trump and his team will be trying to deal with a dangerous international system that is no longer beholden to American military might or economic strength. The problems of an unpredictable North Korea, Chinese belligerence in the South China Sea, and immovable insurgencies in Iraq, Afghanistan, Somalia, Philippines, and elsewhere, represents fundamental challenges to how the US wants the world to operate and do business. Unfortunately, this means trying to repair the "soft power" of the US to the days when it could proclaim the moral high ground through adherence to international laws. Such were the days that the US could convince other countries to join in righteous causes, such as when the US fostered the creation of a large international coalition of military forces (to include Syria) to expel Saddam Hussain from Kuwait in 1991. The US now needs to exercise strategic patience more than ever, while also making long-term commitments to allies in regions that feel threatened by revisionist countries and rising regional powers that are hoping to rollback American influence. Doing so is the only way to prevent the creation of an international system that emerged days before World War One began.

26 Donald Trump running for President. Fox News. June 17, 2015. URL: http://www.foxnews.com/transcript/2015/06/17/donaldtrump-running-for-president.html (Accessed: 18.04.2017)

27 Holley P. The military is not his palace guards,' retired three-star general says of Donald Trump. The Washington Post. March 7, 2016. URL: https://www.washingtonpost.com/news/checkpoint/wp/2016/03/07/the-military-is-not-his-palace-guards-retiredthree-star-general-says-of-donald-trump/?utm_term=.20d01a6bcc7d (Accessed: 18.04.2017); Holley P. Former CIA director: Military may refuse to follow Trump's orders if he becomes president. The Washington Post. February 28, 2016. URL: https://www.washingtonpost.com/news/morning-mix/wp/2016/02/28/former-cia-director-military-may-refuse-to-follow-trumps-orders-if-he-becomespresident/?utm_term=.b6e4099185e8 (Accessed: 18.04.2017)

28 Baldor L. Trump gives Pentagon more flexibility on Iraq, Syria troops. The Washington Times. April 26, 2017, http://www.washingtontimes.com/news/2017/apr/26/trump-gives-pentagon-more-flexibility-on-iraq-syri/(Accessed: 28.04.2017) 


\section{References}

Black H.L. (1960). The Bill of Rights. NYU Law Review, (35). 865-881.

Brands H.W. (2016). The General vs. the President: MacArthur and Truman at the Brink of Nuclear War. New York: Doubleday. 448.

Brooks R. (2016). How Everything Became War and the Military Became Everything: Tales from the Pentagon. New York: Simon and Schuster. 448.

Calhoun F.S. (1993). Uses of Force and Wilsonian Foreign Policy. Kent $(\mathrm{OH})$ : Kent State University Press. 184.

Clark J.F. (2007). The Decline of the African Military Coup. Journal of Democracy, 18 (3). 141-155.

Cross G. (2012). George Washington: A Biography. San Francisco: Hyperink. 28.

Dunlap Ch. J. (1992). The origins of the American military coup of 2012. Parameters, 22 (4). 2-20.

Ellis J.J. (2005). His Excellency: George Washington. New York: Vintage Books. 352.

Feaver P.D. (2009). Armed servants: Agen$c y$, oversight, and civil-military relations. Cambridge (MA): Harvard University Press. 400.

Feaver P.D. (1999). Civil-Military Relations. Annual Review of Political Science, 2 (1). 211-241. DOI: 10.1146/annurev.polisci.2.1.211

Feldman D.L. (1987). Comparative Models of Civil-Military Relations and the U.S. Army Corps of Engineers. Journal of Political and Military Sociology, 15 (2). 229-244.

Friedburg A.D. (1992). Why Didn't the United States Become a Garrison State? International Security, 16 (4). 109-137.

Høiback H. (2013). Understanding military doctrine: a multidisciplinary approach. New York: Routledge. 271.

Huntington S. P. (1957). The Soldier and the State: The theory and politics of civil-mil- itary relations. Cambridge (MA): Harvard University Press. 534.

Huntington S.P. (2006). Political order in changing societies. West Haven: Yale University Press. 512.

Janowitz M. (1961). The Professional Soldier: A social and political portrait. New York: Free Press of Glencoe. 528.

Johnson D.V., Metz St. (1995). American civil-military relations: New issues, enduring problems. Strategic Carlisle (PA): Studies Institute. 36.

Kirby J. [et al]. (2015). A Respectable Army: The Military Origins of the Republic, 1763-1789. Hoboken (NJ): John Wiley \& Sons. 241.

Kohn R.H. (1970). The Inside History of the Newburgh Conspiracy: America and the Coup D'Etat. The William and Mary Quarterly, 27 (2). 188-220.

Kohn R.H. (ed.). (1991). The United States Military under the Constitution of the United States, 1789-1989. New York: New York University Press. 449.

Lasswell H.D. (1941). The Garrison State. American Journal of Sociology, 46 (4). 455468.

Lengel E.G. (ed.). (2012). A companion to George Washington. Hoboken, New Jersey: John Wiley \& Sons. 678.

Maslowski P. (1986). To the Edge of Greatness: The United States, 1783-1865. Williamson M., MacGregor K., Bernstein A. (eds.). The Making of Strategy: Rulers, States, and War. Cambridge: Cambridge University Press. 205-241.

McMaster H.R. (1998). Dereliction of duty: Johnson, McNamara, the Joint Chiefs of Staff, and the lies that led to Vietnam. New York: Perennial. 480.

Williams T.H. (2011). Lincoln and his Generals. New York: Vintage. 400. 


\section{Информация об авторе}

Джахара Матишек, департамент политической науки, Северо-Западный университет

60208, США, Эванстон, Кларка ул., 633

FRANKY@u.northwestern.edu

\section{About the Author}

Jahara W. Matisek, Department of Political Science, Northwestern University

633, Clark St, Evanston, USA, 60208

FRANKY@u.northwestern.edu 